\title{
THE JURISPRUDENCE HADITH ANALYSIS OF BRIBERY AND IT'S IMPACT ON HUMAN LIFE
}

\author{
Nuryamin \\ STAI Baitul Arqam Al-Islamy Bandung, Indonesia \\ Email: knoer09@gmail.com
}

\begin{abstract}
This article discusses the concept of bribery in the perspective of hadith of jurisprudence and its impact on human life. By looking at some definitions of bribery, it is found that all definitions give different meanings, goals, and aspects, there are essence of bribery, or which have similarities to them (such as gratification), because bribery is a social phenomenon and has many patterns making it difficult to define definitions the right and limit the meaning. But a definition that explains the meaning of bribery objectively, namely: Giving given to someone (an official) so that the right becomes wrong and wrong becomes right, because it summarizes the essence of bribery practice and is considered a comprehensive definition of all banned aspects of bribery, so let us choose this. In Qur'ān and Hadīth, Allah forbade his servant to eat bribery property, because this property was included as part of consuming other people's assets with vanity. Even though bribery is called a variety of terms in daily life, such as facilitation payments, tips, etc., the legal status and prohibition cannot change with these various terms. Bribes also have the potential to create hate conflicts and hostility among members of the community. Because in essence, bribery is only a tool for those who hold policies to oppress the weak. On the other hand, those who surrendered their wealth to the recipients of this bribe gave their assets very forcefully.
\end{abstract}

Keywords: Jurisprudence Hadith; bribery; human life;

\section{A. INTRODUCTION}

linguists and jurists differed in defining rishwah. The word rishwah comes from Arabic. Literally, rishwah is a derivation of the word rasha-yarshu which means sticking its head. In al-Mu'jam alWasith it is mentioned rasha al-farakhu, meaning the quail sticks his head to his mother (Mujamma' al-Lugah al-'Arabiyah, 2004, p. 347). Ibn al-Athir defines, الرُشّوة - الرِّشوة namely the effort to fulfill the needs (interests) with a pretend / artificial attitude. The origin of rishwah comes from الرِشاء which is the rope that conveys the bucket to (source) water. الراشي is a person who gives to be helped in falsehood (bribe), المرتشي is a person who is bribed (takes steam bribes), while الريائش is the liaison between bribers and those who are bribed (Ibn al-Athir, 1963, p. 226)

As for terminology, the fuqaha varies according to the definition of risywah, including: a) According to Al-Mäliki, rishwah is "Giving given to someone (official) so that the right becomes wrong and wrong becomes right" (Ibn al-'Arabi, 1997, p. 65). b) While al-'Asqalani, rishwah is "any money given to officials as compensation for vanity assistance, or giving to people whose duties and obligations must do so and may not accept anything from their profession (except salaries)" (Ibn Hajar, 2000, pp. 271-272) c) Yusuf al Qardawi said, rishwah is "money given to the ruler or employee, so that the ruler or employee imposes a favorable sentence, or a law which harms his 
opponent according to his will, or prioritizes or is postponed because there is some interest and so on" (al-Qaradawy, 1980, p. 320) d) Muhammad 'Ali at Tahawi in his work said, rishwah is "the property provided that he (who is given) must help him and who gives unconditionally is called a gift" (al-Tahawy, 1996, p. 863) e) Al-Fayyumi in his work said, rishwah is "someone gives to a ruler or someone else in order to intervene and direct as he wishes, and be privileged from others" (alFayyumi, 1987, p. 87); and f) While Ahmad Mukhtar in Mu'jam al-Lugah al-'Arabiyah al Mu'asirah, rishwah is "Incorrect giving for certain purposes, or to justify wrong (الباطل) and blame the right (الحق)" ('Umar, 2008, p. 897).

By looking at some of the above definitions that all definitions give different meanings, goals, and aspects, there is an essence of bribery, or that there are similarities to it (such as gratification), because bribery is a social phenomenon and has many patterns making it difficult to determine the exact definition and limit its meaning. But according to ash Syịsyāni the first definition is more appropriate, because it has explained the meaning of risywah objectively, namely: Giving given to someone (official) so that the right becomes wrong and wrong becomes right, because it summarizes the essence of bribery practice and is considered the definition comprehensive of all aspects of bribery that are forbidden, so it is possible to choose this. As for getting a more complete and most comprehensive definition of having all aspects and bribery offenses with provisions in all cases it will be very difficult to achieve (al-Sisyani, 1991, pp. 13-15).

But from the above definitions we can draw a conclusion that acts of bribing or accepting bribes are things that are considered contrary to the norms of goodness, both in the review of positive law or in the view of Islam. It's just that, Islam puts this bribery case as an action that not only affects the quality of life of someone in the world, but also has consequences in the hereafter.

\section{B. Method}

This article is written using a library survey method (Gunasekera, 2010) The concept of the rishwah is elaborated from various sources (Tafseer-Hadith books) written by muslim tafseer-hadith scholars, both classical and contemporary scholars. The results are narrated in the form of exposures that illustrate how the law of rishwah in Islam.

\section{Result and Discussion}

\section{Hadiths about Rishwah (Bribery)}

In the segment of the hadith discussion using the thematic method (minhaj al-hadith al-maudŭ'i) is almost the same as the discussion of thematic interpretations, namely collecting several traditions in one topic from different sources and then analyzing and doing criticism of sanad, matan, and explanation, then concluded general theory to be guided in the application so that it is in accordance with the basics of the Nabawi method.

The searching Hadiths related to the topic, the author uses three digital Hadith softwares, to make it easier to trace the existence of hadith, namely: al-Maktabah al-Shamilah 3.5, and Mausŭ'ah kutub al-tis'ah Arabic and Indonesian versions. In the search, the author found at least 26 Hadiths that were in accordance with the topic of discussion from several sources (Hadith books), both 
explicitly (having explicit meaning, and explicit) and implicit (having meaning not explicitly explaining).

The systematics of writing traditions related to risywah (bribes) that have been traced are as follows: a) grouping hadith according to their context; b) the author does not list all hadiths with several considerations: 1) have similar meanings even though the editor is different; 2) have the same sanad line; 3) simplifying writing; 4) the author still lists the matan hadith pieces (ațräf alhadis) in the sub discussion of syarh al-hadith.

\section{a. The First Group}

Prizes related to duties and positions: Shahih al-Bukhari no. 2407, 6145, 6464, 6639, 6658, ihahih Muslim no. 3413, 3414, sunan abu Daud no. 2557, Ahmad no. 22492, sunan ad-Darimi no. 1609 (al-Darimi, 1337, p. 483).

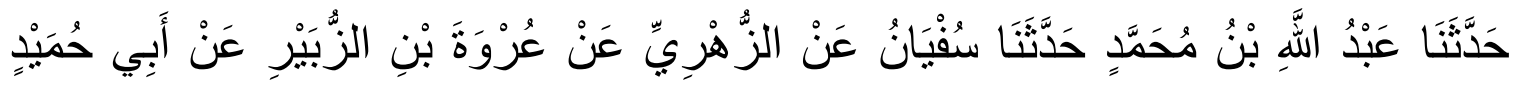

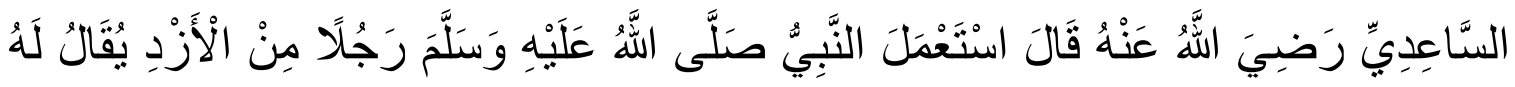

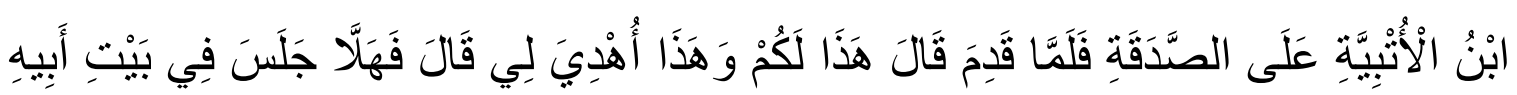

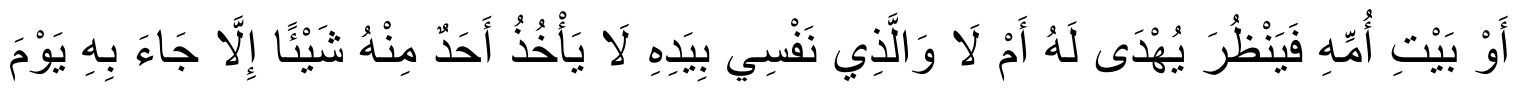

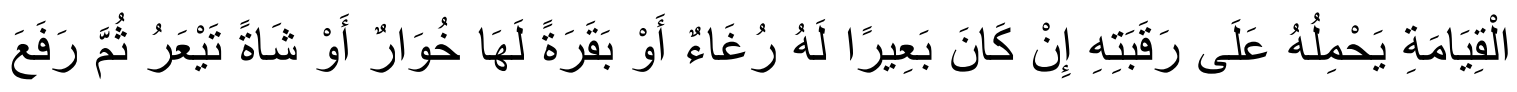

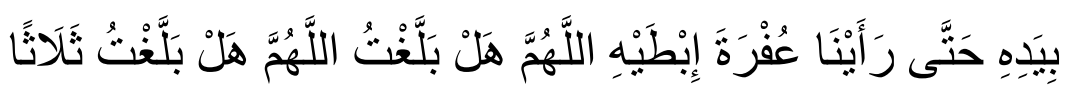

(BUKHARI - 2407): Abdullah bin Muhammad has told us, Sufyan has told us, from al-Zuhry, from 'Urwah bin Az Zubair of Abu Humaid al-Sa'idiy ra, he said; The Prophet PBUH employed a man from the Al azdiy tribe as a zakat collector. When he came from his assignment, he said: "This is for you as zakat and this is given to me". He said: "Let him dwell in the house of his father or his mother and see whether it is given for him or not. And for the sake of the Essence of my soul in His hand, not one will take anything from zakat unless he will come on the Day of Judgment the top of his neck is a screaming camel, or a softening cow or bleating goat ". Then he raised his hand so that it was seen by us in his white armpit and (said,): "O Allah, surely, I have conveyed, surely, I have conveyed" ... three times ". (Narrated by Al-Bukhari) (al-Bukhari, 2002, p. 630).

Asbāb al-wurŭd, if we look at the traditions traced from several sources with editors who are somewhat different, but have similar meanings. Starting from the assignment of the Prophet by raising a number of zakat employees ('āmil az-zakat) including Al-Atbiyah (Bukhari) or Al-Latabiyah (Muslim) from the Azad tribe who are in charge of managing the zakat of the ummah in several regions, amil zakat, they get and receive gifts from the muzakki (zakat people). After completing his duties, Amil reported his work to the Prophet Muhammad, and (other zakat officers) while saying: "This (gift) for you and this for me", the Prophet spontaneously was angry and responded with his words: هَلَّا جَلَسنَ فِي (Let him stay in his father's or mother's house and then he sees whether it is true that it was given for him or not ?!) in the history of Bukhari which is still sourced from the same

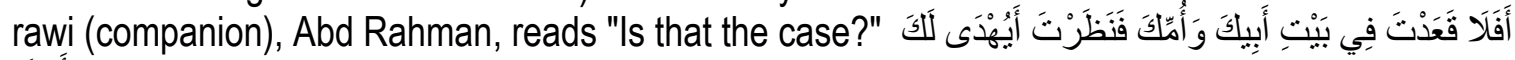
أَمْ لَ (don't you just sit at your father's house or your mother then observe, do you get a gift or not?). 
Then the Prophet's qawly hadith with some editors or the meaning and purpose, made as a general method "may not accept any prize if related to duties and positions" which then al-Bukhari placed the above hadith in one chapter "people who may not receive gifts for certain reasons".

Sharh al-hadith, if referred to as original sources, the author places the above hadith in a different chapter, namely Bukhari in the chapter "people who cannot accept gifts for certain reasons", Muslims in the chapter "forbidden gifts for officers", Abu Dawud in the chapter "presents the officers, Musnad Ahmad at "bāqi musnad al-anșār", and to Sunan ad-Darimi in the chapter "gifts for zakat managers for whom". There was a slight difference in male and tribal names (qabilah) which became the asbāb al-wurŭd of the hadith above, in the history of al-Bukhari his name is lbn Utbiyah from qabilah al-Azad, Muslims have two versions: first Ibn Utbiyah's name from al-Azad; his second name is Ibn Lutbiyah from al-Asd, as well as Ahmad named Ibn Lutbuyah from qabilah al-Azad, while the history of Abu Dawud named Ibn Utbiyah comes from the qabilah al-Azad. The real name of the man is Abdullah (al-Sadiqi, 2005, p. 1329).

Ibn Hajar in his work Fath al-Bāri, is related to "people who cannot accept gifts for certain reasons", because of concerns, which have a negative impact (Ibn Hajar, 2000, p. 271). Salaf scholars are also reluctant to accept prizes for avoiding falling into disobedience (wara' or tawarra') such as the attitude of Umar bin Abdul Aziz who refused a gift from someone, and the gift giver argued: "why did you not accept the gift even though the Prophet and successor (khulafā 'ar-Rāsyidịn) they received a prize? "then Umar replied: it is true, the hadiyah in the Prophet's era remained hadiyah, but in the present, it is rishwah / bribe or in another history "indeed for the Prophet and gifted friends, but for employees after they are risywah". Then the fragment of the hadith: "Let him stay in the house of his father or his mother and then see whether it is granted for him or not" and several different editors and different sources, but have a unified meaning, as mentioned above. The scholars then made the above hadith chunks as a general method or the formula should not allow officials to receive prizes.

Prizes are basically highly recommended in Islam because it can have a positive impact on people's lives, can unite the heart, foster a sense of love and affection, etc., Rasul SAW said: "Give each other gifts then you will love each other". (Bukhari No. 594) (al-Bukhari, 1375, p. 155). Even the Prophet Muhammad PBUH advocated repaying a gift with a better, at least good words: "Whoever gets the favor, say to the giver: hopefully Allah will make a better payment." (At-Tirmizi no. 2035 ) (al-Tirmidhī, 2000, p. 460).

However, giving related to the position or duty of a person in the Shari'ah perspective can be included in the prize category or risywah, in this case related to the above problems there are several views of scholars: a) if the gift is not related to one's position or profession, then it is permissible, like someone who is used to receiving gifts from relatives or friends before becoming an official; b) gifts that he never received before becoming an official, or used to accept but, better than quality and quantity aspects, such as before serving, the prize was just plain cloth, but once he became an official the prize was silk, then the jumhur ulama forbade him (al-Bahtiti, 2012, p. 20). The above opinion was inspired by the words of the Prophet: "Let him stay in his father's or mother's house and then he sees whether it was given for him or not" (al-Bukhari, 2002, p. 630). While the word بلغ shows the responsibility of the Prophets and Apostles to deliver the message of God, and will be held accountable on the day of vengeance.

\section{b. The Second Group}


Cheating and professionalism in occupation: șahih Muslim no. 3415 , sunan al-Tirmizi no. 1255 , sunan Abu Dawud no. 3110, Ahmad no. 17056, 17059, 22495.

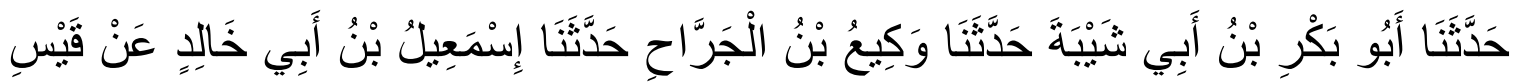

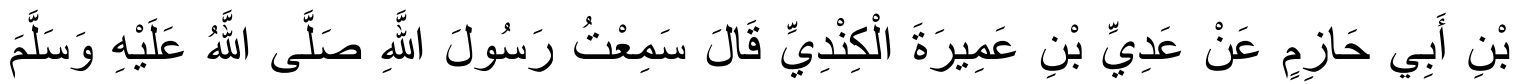

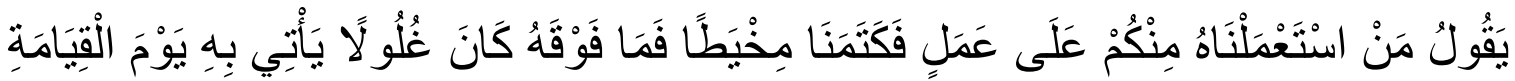

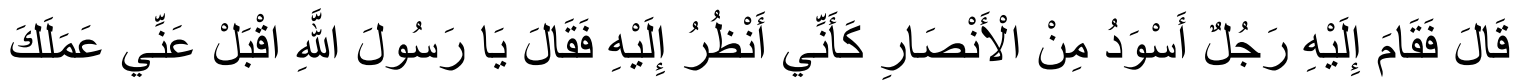

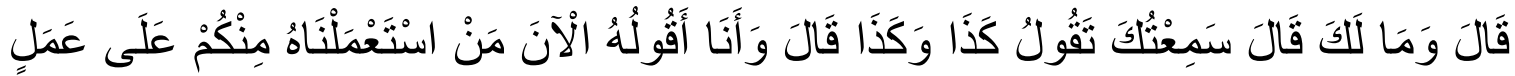

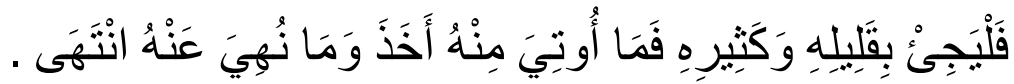

(MUSLIM - 3415): Abu Bakar b. Abi Shaibah has told us, Waki'b. Jarrah has told us, Ismail b. Abi Khalid has told us, from Qais b. Abi Hazim, from 'Adi b. Amirah Al Kindi, he said, "I heard the Prophet PBUH said:" Whoever of you I lift up on a charity, then he hides from us (though) a needle, or something smaller than that, then it is ghulul (theft) which he will bring on the Day of Judgment. "'Adi bin' Amirah said," Then a black man from Ansar - it seems I once saw him - stood up saying, "O Messenger of Allah, then I will take back the task that you have ever charge me! " He asked back: "What's wrong with you?" he replied, "I have heard that you have said this and like this." He said: "Now I say, that whoever of you I am assigning to a charity should come either with little or a lot, what is given for him he may take, and what is forbidden for him, then he must be able to restrain himself. " "(Narrated by Muslim no. 1833) (Muslim, 1999, p. 766).

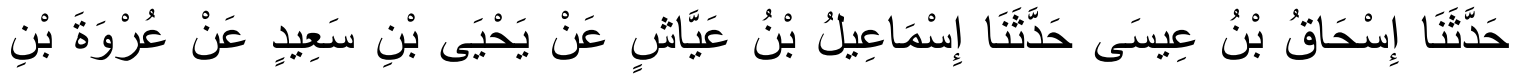

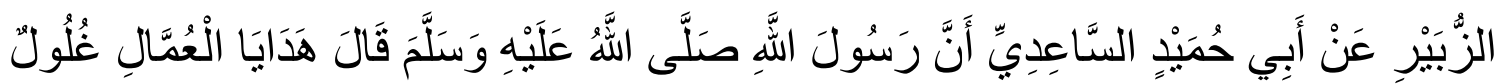

(AHMAD - 22495): Ishaq b. 'Isa has told us, Isma'il b. 'Ayyash has told us, from Yahya b. Sa'id, from Urwah b. al-Zubair, from Abi Humaid al-Sa'idi, that the Messenger of Allāh W said: "the prize for the coolies is ghulul (the result of the ghanimah taken secretly before its distribution) (HR Ahmad no. 23999) (Ahmad, 1998, p. 1754).

Sharh al-hadith, hadiths above is to strengthen and reinforce the position of hadiths in the first group, about the prohibition of receiving gifts for the employees, officers, or related to the profession, even Imam Nawawi says not only unlawful but a betrayal of the mandate and the office (the oath) (al-Nawawi, 1392, p. 219). It is clear that gifts received or given to judges and officials fall into the category of rishwah, because of them, before becoming an official they never get a prize (al-Sadiqi, 2005, pp. 1624-1625).

\section{c. The Third Group}

Practices rishwah in the judiciary: Sunan Abi Dawud no 3074, and Sunan al-Tirmizi no. 1256. 


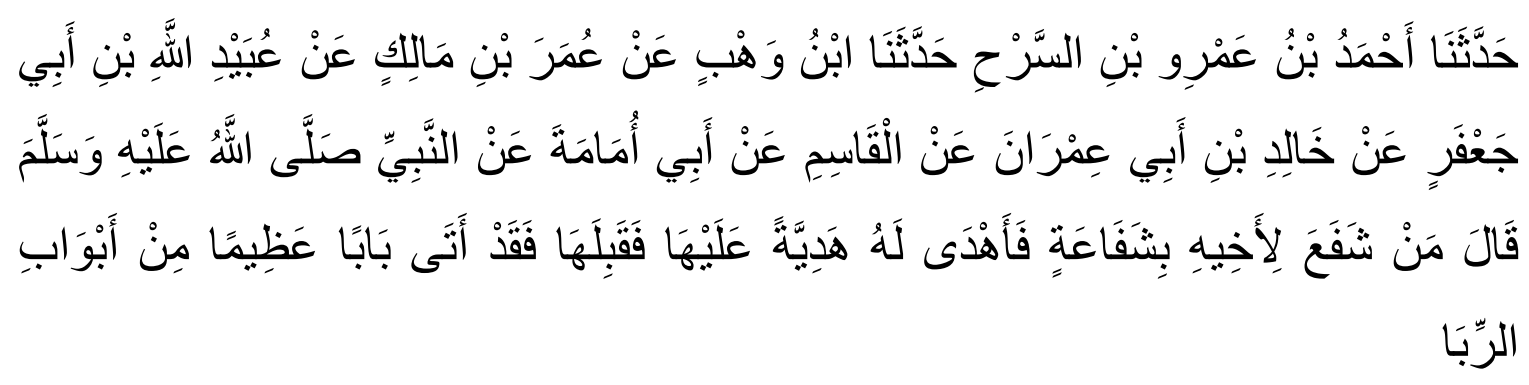

(ABU DAWUD - 3074): Ahbad b. 'Amr b. al-Sarh told us, Ibn Wahb had told us, from Umar b. Malik, from Ubaidullah b. Abu Ja'far, from Khalid b. Abu Imran, from al-Qasim, from Abi Umamah, from the Prophet PBUH, he said: "Whoever pleads for his brother with a request, then his brother gives him a gift because of the request then he accepts it, so really, he has come to one of the big doors between the doors of usury. "(Narrated by Abu Dawud) (Abu Dawud, 1417, p. 635).

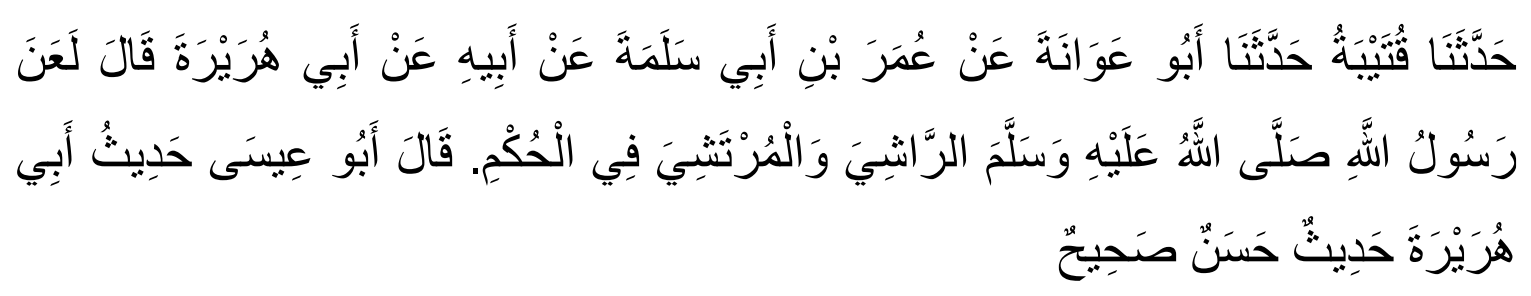

(AL-TIRMIDZI - 1256): Qutaibah has told us, Abu 'Awanah told us, from Umar b. Abi Salamah, from his father, from Abh Hurairah, he said; The Prophet Muhammad cursed the bribe and was bribed in legal matters. Abu Isa said; The hadith of Abu Hurairah is a hadith hasan saheeh. (Narrated by At-Tirmizi) (al-Tirmidhi, 1417, p. 315).

Sharh al-Hadith, Abu Dawud explained the hadith above, that when people (judges or officials) are asked for help then they take gifts from people who are helped, then only he asks for rewards from what has been done, then when someone takes something, related to the task, the position, and the profession, it will affect the intention and the good. Helping is kindness and is not worthy to take wages (benefits from the good done) (al-'Ibad, n.d., p. 35).

Al-rāshi is the person who gave risywah (bribe) while al-murtashi is a person who accepts bribes, who then both get the curse (far from the mercy of Allah), because both have the same motivation and purpose, namely for falsehood and tyranny, as forbidden bribe the judge for changing the right to vanity (Ibn al-Athir, 1973, p. 173). Al-Kankuhi in his al-Kawkab said, if a judge is bribed to decide a law that contradicts the truth value, then he is cursed, even though his decision is in accordance with sharia law 'or under the law (contrary to the Shari'ah law), because he sacrifices (bribes) to refuse evil is permitted (jāiz) which is tyrannized not for those who abuse, and the Prophet PBUH, once gave something to the person who was concerned about his crime (al-Kankuhi, 1975, p. 345).

Al-Qasimi mentions (al-Qasimi, 1957, p. 1992), Ibn Mas'ud said that rishwah can occur anywhere, who asks for a request (to the judge) to return his property, or reject tyranny, then he is given a gift and receives it, then it belongs to the category suht (bribe / rishwah). Then he (ibn Mas'ud) was asked: $O$ Abu Abdurrahman, as far as we know that there is only the law? so he said: if qadi

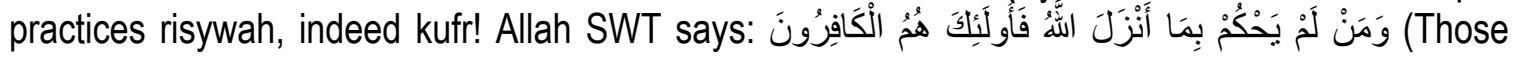
who do not decide according to what Allah has sent down, they are those who disbelieve). Ibn 
Taimiyah, as cited by al-Kahlani, asserted that gifts from helping people: such as someone pleading with a judge, or an official to restore his rights, or taking the rights of an indigent person who is still detained ... then all help, whether that must be done or which must be abandoned, may not (illegitimate) receive a gift (al-Kahlani, 2006, p. 94).

\section{d. The Fourth Group,}

The practice of rishwah in life: Ahmad no. 6246, 6489, 6490, 6536, 6689, 21365.

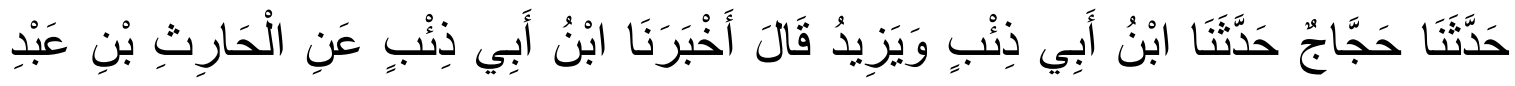

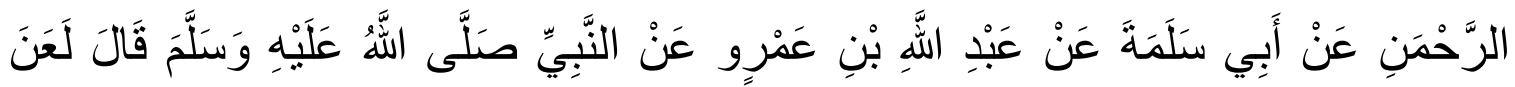

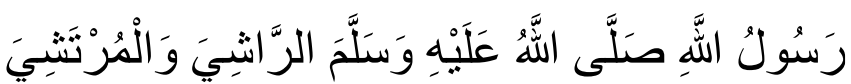

(AHMAD - 6489): Hajjaj has told us, Ibn Abi Dhi'b has told us, from al-Harith b. Abd al-Rahman, from Abi Salamah, from Abdillah b. 'Amr, he said; "The Prophet Muhammad PBUH cursed the bribe and recipient of bribes." And Yazid said: "God despises the giver and accepts the bribe" (Ahmad, 1998, p. 513).

Sharh al-hadith, in the third group specific mention of ethics and a judge or official who receives gifts from people who request assistance, but this section is more specific about the substance of bribery, that bribery is very dangerous for social life, damaging religion and the world, individuals, and many people, from that the perpetrators of the risywah were condemned and cursed by Allah and His Messenger (al-Kahlani, 2006, p. 96).

\section{e. The Fifth Group}

The Prophet received a gift: Sunan al-Nasa'i no. 3698

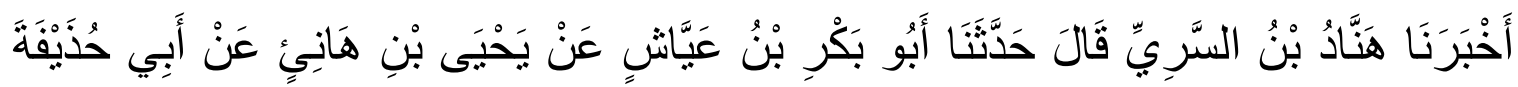

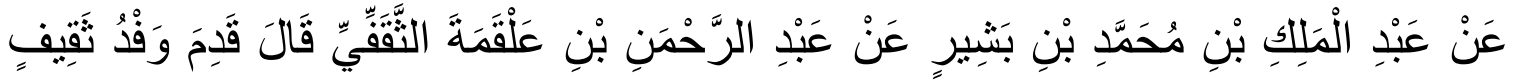

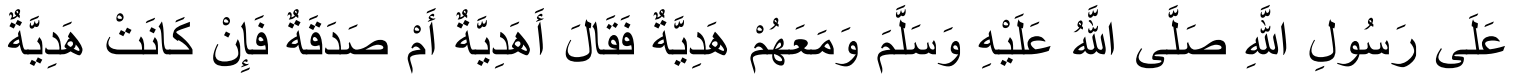

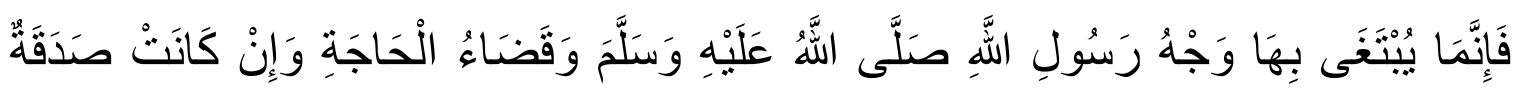

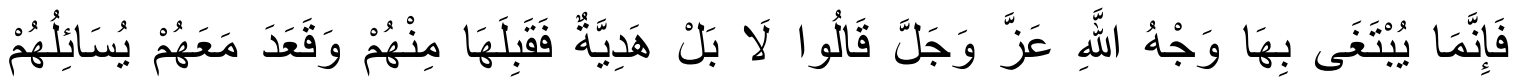

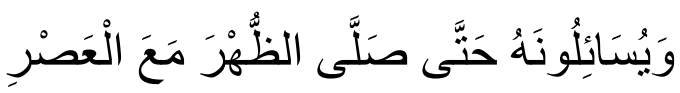

(AL-NASAI - 3698): Hannad b. Al-Sari told us, he said, Abu Bakr b. 'Ayyash told us, from Yahya b. Hani' from Abu Hudzifah, from Abdul Malik b. Muhammad b. Basyir, from 'Abdurrahman b. 'Alqamah al-Thaqafi, he said, "The Thaqif envoy came to the Prophet Muhammad with a gift, he then asked:" This is some gift or alms. If the prize is for expecting the blessing of the Prophet sallallaahu alaihi wasallam and fulfilling the needs, if it is charity then it is because of expecting the blessing of Allah Almighty. "They replied," No, this is a gift". So, he accepted and sat down together 
they, he asked them and they asked him until he performed the Zuhr and Asr prayer. "(Narrated by al-Nasa'i) (al-Nasa'i, 2005, p. 906).

Sharh al-hadith, Ibn al-'Arabi in his work said, the Prophet and his family should not (illegitimate) accept alms but, may (halal) receive a gift. Various reasons (wisdom) why can't be temporary while prizes may be: 1) alms motivation is a reward at the end, and illustrates the nobility that gives and low who receives because it needs help and attention; 2) motivational gifts to establish closeness (taqorrub) to someone and glorify it, because it has advantages and glory; 3 ) reward characters are rewarded in the world, as the Prophet repays gifts from people, while alms in the afterlife, and who deserves to repay only Allah (Ibn al-'Arabi, 1997, p. 127). Likewise there are several reasons for the scholars why the Prophet SAW, received a gift: 1) was devoted to the Prophet PBUH (Wizarah al-Awqaf wa al-Syu'un al-Islamiyah, 2004, p. 26).; 2) the purpose of da'wah, as with the acceptance of the gift will foster a sense of love and affection.

\section{Sanad and Matan's Criticisms}

In the study of hadith, the criticism of sanad and hadith is very important, because it involves the existence, quality, and authenticity of hadith. To determine the hadith maqbul (accepted) or mardud (rejected) must be seen from two aspects namely sahad and matan, then the study of the criticism of sanad and matan will be very important. Muslim priests in their Muslim sahqaddimah declare: always learn (chapter / knowledge) about the lack of narrators / criticism sanad (jarh wa ta'dil), how to convey hadith, and give fatwa when asked, therefore, study the hadith and its derivatives, including one that is urgent in Islam: both in matters of halal, haram, orders, prohibitions, targib and tarhịb (Muslim, 1999, p. 31). Ibn al-Mubārak said: isnād is part of religion, if there is no isnād, people will say what they want. Based on the sources of hadith and the statements of the scholars, it can be concluded that the hadiths that have been traced to bribery (risywah) are included in the category of authentic hadith (maqbul) and deserve to be used as hujjah.

\section{Rishwah's Bad Impact}

\section{a. Impact on the Person}

It cannot be denied that rishwah is a chronic disease that can undermine one's identity. Thus, because of the act of rishwah (bribery), both the giver or recipient can harm the highest moral foundation, namely al-'Adl (justice) and Ihsan (doing good). These two characters are indicators of one's bad character and behavior. While good and bad someone's morality becomes a measure of his faith in Allah SWT. Allah says:

"Verily, Allah commands (you) to be fair and do good, give to the relatives, and Allah forbids evil, evil and hostility. He teaches you so that you can take lessons." QS. An-Nahl: 90.

If this fair character is lost from someone, then the bad thing that will happen is the abuse of authority and position mandated to him. His authority and position is only an opportunity to exploit as much as possible illegal profits in order to enrich himself and others beyond his legitimate rights (Utomo, 2003, p. 15). 


\section{b. Impact on the Economy}

In the economic context, the behavior of giving and receiving bribes which are part of acts of corruption can hinder a country's economic growth. From the results of research conducted by Paolo Mauro, the existence of corruption will disrupt the transmission mechanism of income and wealth so that the emergence of corruption will lead to income gaps. Using cross-country studies, Mauro (Mauro, 1996, 1997, 2004) shows that corruption is negatively related to economic growth and damages existing investments. This means that if corruption increases, domestic investment will be disrupted and economic growth will decline. Mauro (Mauro, 1997) also shows that the high level of corruption will reduce the amount of government expenditure, especially in the field of social security and public welfare payments.

\section{c. Impact on the Community}

Bribery carried out by many parties will cause chaos in the order of life in society and the state. AlQardhawi said, "It is not surprising that Islam forbids bribery and being tough on all parties involved in the practice. Thus, because the spread of bribery in the community means rampant destruction and injustice, in the form of law without the principle of truth or indifference to law. with truth, put first what should be ended and end what should take precedence, also rampant mental opportunism in society, not the mental responsibility of carrying out obligations" (al-Qaradawy, 1980, p. 464).

\section{CONCLUSION}

Rishwah according to the Qur'an and Hadith is something (wealth) given to someone with the aim of getting something desired in a vanity way. Or something that is given to someone who has influence or policy, whether in order to win a sleaze or obstruct something right. In the Qur'an and the Hadith Allah forbids His servants to eat risywah property, because this property is included as part of consuming other people's assets with vanity. Even though in daily life risywah is called a variety of terms, such as pelican money, tips, bribes, bribes, etc., still the legal status and prohibition cannot change with the various terms.

The practice of giving bribes to win falsehood and defeat what is actually is the culture of the Jews. God humiliated them because of this behavior, even because of the tyranny they used to make, God forbade them to be halal. In the Qur'an and Hadith there are several threats to people who commit bribery, both implicit (general) and explicit (specifically). Even the Messenger of Allah threatened with the threat of cursing the bribery practitioners. Thus, it shows that risywah is part of the classification of great sins.

The practice of rishwah is a chronic disease that can undermine one's identity. Thus, because of the act of risywah (bribe / bribe), both the giver or recipient has injured the highest moral foundation, namely al-'Adl (justice) and Ihsan (doing good). These two characters are indicators of one's bad character and behavior. While good and bad someone's morality becomes a measure of his faith in Allah SWT. In addition, bribery also has the potential to create hate and hostility conflicts among members of the community. Because in essence, rishwah is only a tool for those who hold 
policies to oppress the weak. On the other hand, those who surrendered their wealth to the recipients of this bribe, gave their assets very forced.

\section{REFERENCES}

Abu Dawud, al-S. (1417). Sunan Abi Dawud. Riyad: Maktabah Ma'arif.

Ahmad, al-S. (1998). Musnad Ahmad. Riyad: Bayt al-Afkar.

al-Bahtiti, M. b. M. (2012). Hukmu Hadaya al-'Ummal. Mukhbah al-l'lam al-Jihadi.

al-Bukhari, M. b. I. (1375). Adab al-Mufrad. al-Qahirah: Matba'ah al-Salafiyyah.

al-Bukhari, M. b. I. (2002). Sahih al-Bukhari. Bayrut: Dar Ibn Kathir.

al-Darimi, 'Abdullah b. 'Abd al-Rahman. (1337). Sunan al-Darimi (Vol. I). Karachi: Qadimi Kutub Khonah.

al-Fayyumi, al M. (1987). al-Misbah al-Munir. Bayrut: Maktabah Lubnan.

al-'Ibad, 'Abd al-Muhsin. (n.d.). Syarh Abi Daud: Maktabah Shamilah (Vol. XIX). Maktabah Shamilah.

al-Kahlani, al-S. (2006). Subul al-Salam Sharh Bulugh al-Maram (Vol. III). Riyad: Maktabah Ma'arif.

al-Kankuhi, R. A. (1975). al-Kaukab al-Durri ‘ala Jami' al-Tirmidhi. Lucknow-India: Matba'ah Nadwah al-Ulama'.

al-Nawawi, A. Z. (1392). Syarh Sahih Muslim (Vol. XII). Bayrut: Dar Ihya al-Turath al-'Arabi.

al-Qaradawy, Y. (1980). al-Halal wa al-Haram fi al-Islam. Bayrut: Maktabah al-Islamiyyah.

al-Qasimi, J. al-Din. (1957). Mahasin al-Ta'wịl (Vol. III). al-Qahirah: Dar Ihya al-Turath al-'Arabi.

al-Sadiqi, M. A. (2005). 'Awn al-Ma'bud. Bayrut: Dar Ibn Hazm.

al-Sisyani, 'Abd al-Wahhab. (1991). Dawr al-Qoyim al-Ghaibah allati Tahkumu binai al-Fard fi Mukafahat Jarimat al-Rishwah. Riyad: al-Markaz al-'Arabl II al-Dirasat al-Amniyyah wa alTadrib.

al-Tahawy, M. A. (1996). Kasyaf Istilat al-Funun wa al-'Ulum (Vol. I). Bayrut: Maktabah Lubnan.

al-Tirmidhi, M. b. 'Isa. (1417). Sunan al-Tirmidhi. Riyad: Maktabah Ma'arif.

al-Tirmidhī, M. ibn ‘̄̄sā. (2000). Sunan al-Tirmidhī. Vaduz, Liechtenstein : Jam‘iyat al-Maknaz alIslamī,.

al-Nasa'i, A. (2005). Sunan al-Nasa'i (Vol. II). Bayrut: Dar al-Fikr.

Gunasekera, C. (2010). Students Usage of an academic Library: a user survey conducted at the Main Library University of Peradeniya. Journal of the University Librarians Association of Sri Lanka, IV(1), 43-60. 
Ibn al-'Arabi, al-M. (1997). 'Aridat al-Ahwadhi (Vol. VI). Bayrut: Dar al-Kutub al-'Ilmiyyah.

Ibn al-Athir, al-J. (1963). al-Nihayah fi Garib al Hadith wa al-Athar (Vol. II). Bayrūt: Maktabah alIslamiyyah.

Ibn al-Athir, al-J. (1973). Jami' al-Usul fi Ahadith al-Rasul (Vol. X). Bayrut: Maktabah al-Hilwani.

Ibn Hajar, al-'Asqalani. (2000). Fath al-Bari (Vol. V). Riyad: Dar al-Salam.

Mauro, P. (1996). The Effects of Corruption on Growth, Investment, and Government Expenditure (SSRN Scholarly Paper No. ID 882994). Rochester, NY: Social Science Research Network. Retrieved from https://papers.ssrn.com/abstract=882994

Mauro, P. (1997). Why Worry About Corruption? WASHINGTON, D.C.: INTERNATIONAL MONETARY FUND. https://doi.org/10.5089/9781557756350.051

Mauro, P. (2004). The Persistence of Corruption and Slow Economic Growth. IMF Staff Papers, $51(1), 1-1$.

Mujamma' al-Lugah al-'Arabiyah. (2004). al-Mu'jam al-Wasit. al-Qahirah: Maktabah al-Shuruq alDawliyyah.

Muslim, A. al-Husain. (1999). Sahih Muslim. Riyad: Bayt al-Afkar.

'Umar, A. M. (2008). Mu'jam al Lugah al-'Arabiyah al-Mu'asirah, (Vol. I). al-Qahirah: 'Alam alKutub.

Utomo, S. B. (2003). Fiqih aktual: jawaban tuntas masalah kontemporer. Jakarta: Gema Insani Press.

Wizarah al-Awqaf wa al-Syu'un al-Islamiyah. (2004). al-Mausu'ah al-Fiqhiyah al-Kuwaitiyah (Vol. XLIII). Kuwait: Wizarah al-Awqaf wa al-Syu'un al-Islamiyah. 